\title{
Are the posterior bracket placement patterns reliable?
}

Fabiano Dalla Lana Mattiello ${ }^{a}$, Marcelo Bichat Pinto de Arruda ${ }^{a}$, Natália Lima Xaviera ${ }^{a}$ Thaís Gelatti Bortoly ${ }^{a}$

\begin{abstract}
Objective: Investigate the marginal ridges leveling accuracy of Alexander and Viazis bracket placement methods. Methods: Eighty pairs of dental casts were selected, with complete permanent dentition, without occlusal wear or restorations. A linking line between mesial and distal ridges of posterior teeth was done to measure the occlusal thirds with digital caliper. The means, obtained from 3 different examiners, were compared with the values of Alexander and Viazis' equations through One-way ANOVA with $\alpha=0.05$.

Results: The second premolar placement value $(x)$ suggested by the authors showed no difference in comparison to the occlusal third size of the sample teeth $(p>0.05)$, however for the first premolars, a significant difference was found $(p<0.001)$. The value adopted for positioning on the first permanent molars $(x-0.5 \mathrm{~mm})$ is consistent with the size of the occlusal third of these teeth $(p=0.0531)$. A significant difference was also found for the second permanent molars bracket positioning between the predefined value $(x-1 \mathrm{~mm})$ and the sample $(p<0.001)$. Conclusions: The vertical positioning values proposed by Alexander and Viazis for placement of second premolars and first permanent molars do contribute to the leveling of marginal ridges, which cannot be applied for the values recommended for the first premolars and second permanent molars.
\end{abstract}

Key words: Dental bonding; Orthodontic appliances; Orthodontic brackets

\section{Os padrões de posicionamento posterior de bráquetes são confiáveis?}

\section{RESUMO}

Objetivo: Verificar a precisão no nivelamento de cristas marginais dos padrões de posicionamento de bráquetes de Alexander e Viazis em dentes posteriores.

Métodos: Foram selecionados 80 pares de modelos de gesso com dentição permanente completa e sem desgastes ou restaurações oclusais. Uma linha ligando as cristas marginais mesial e distal dos dentes foi demarcada, visando a medição do terço oclusal com um paquímetro digital milimetrado. As médias obtidas de 3 examinadores foram comparadas com os valores propostos por Alexander e Viazis através do teste de One-Way ANOVA com $\alpha=0,05$.

Resultados: O valor (x) proposto para o posicionamento nos segundos pré-molares não apresentou diferença com a dimensão do terço oclusal da amostra $(p>0,05)$; entretanto para os primeiros pré-molares houve diferença significativa $(p<0,001)$. O valor de posicionamento adotado para os primeiros molares permanentes $(x-0,5 \mathrm{~mm})$ foi condizente com a dimensão do terço oclusal destes dentes $(p=0,0531)$. Houve diferença significativa entre o valor $(x-1 \mathrm{~mm})$ predifinido para os segundos molares permanentes e a amostra $(p<0,001)$.

Conclusões: Os valores de posicionamento de acessórios propostos por Alexander e Viazis para os segundos pré-molares e para os primeiros molares permanentes promovem o nivelamento das cristas marginais, entretanto o mesmo não ocorre para os primeiros pré-molares e segundos molares permanentes.

Palavras-chave: Adesão; Ortodontia; Brackets ortodônticos a Department of Orthodontics, School of Dentistry, Universidade Federal do Mato Grosso do Sul, Campo Grande, MS, Brazil 


\section{INTRODUCTION}

Normal occlusion is characterized by a balanced relationship between teeth, basal bones and cranial anatomy, with proximal dental contact points, proper axial inclinations, and normal correlations with all surrounding tissues. It constitutes one of the major requirements at the end of a successful orthodontic treatment, and these outcomes may be assessed by many evaluation methods [1].

Among various criteria, the American Board of Orthodontics assessment evaluates dental alignment and marginal ridges leveling of the finished orthodontic treatments. According to this method, differences greater than $0.5 \mathrm{~mm}$ in the height of the marginal ridges between adjacent teeth are considered clinically significant and require correction [2].

Previous study reported that one of the key factors hindering orthodontic treatment from achieving an ideal occlusion is the inaccurate positioning of brackets $[3,4]$. This inaccuracy results in a lack of root parallelism, of mutually protected guidances and also in inadequate intercuspation $[3,5]$. Therefore, when brackets are not properly positioned, arises the need to place compensatory bends on the archwires [6] or rebond brackets, which results in increased treatment time $[7,8]$.

In view of the need to position brackets correctly, several authors have devised bracket placement techniques. Previous studies $[9,10]$ recommended that brackets should be placed at the center of the buccal surface, but variability in tooth size hindered the desired tooth leveling [11]. Due to this failure, Alexander [12] and Viazis [13] introduced a placement pattern based on the height of premolars, while Ricketts [14] and Kalange [11], used the marginal ridges as reference for positioning brackets.

Aiming an enhanced precision in the placement of brackets and reduce the amount of compensatory bends in the archwires as well as bracket rebondings, the objective of this study was to determine whether the vertical placement patterns for positioning brackets on posterior teeth using the unworn oclusal edges as parameter introduced by Alexander and Viazis do indeed succeed in leveling the marginal ridges.

\section{METHODS}

Dental casts were randomly selected from among the patients archive of the postgraduate program in Orthodontics at the Federal University of Mato Grosso do Sul School of Dentistry, Brazil (UFMS). This research was analysed and approved by the ethics committee of the university (protocol 2080/2011).

The sample size, determined with a power of $80 \%$ and a significance level of $5 \%$, consisted of 80 pairs of casts. Only the casts that met the prerequisites were selected, with a complete permanent dentition, including the second molars, without occlusal wear or restorations in any of the posterior teeth, independent of the type of malocclusion established and sex or age of the patient.
First, the long axis of posterior teeth was traced with a $6 \mathrm{~B}$ soft pencil lead (Staedtler, Nuremberg, Bavaria, Germany). The root inclination, viewed in the buccal and occlusal aspects of each tooth, was used as reference for an accurate tracing [11].

Later, both mesial and distal marginal ridges [11] of each tooth were traced using a Staedtler ${ }^{\mathrm{TM}}$ Basic compass (Staedtler), which featured a steel leg and a 6B soft pencil lead. The steel leg was supported at the center of the marginal ridge of the tooth in question, and the compass was carefully aligned relative to the long axis of each tooth in the buccolingual and mesiodistal directions. After alignment, the pencil lead touched the buccal surface at the mesial and distal portions, tracing marks relative to the marginal ridges height [15] (Figure 1). Then, the mesial and distal demarcation lines were manually connected with a $6 \mathrm{~B}$ soft pencil, taking into account the teeth's long axis inclination.

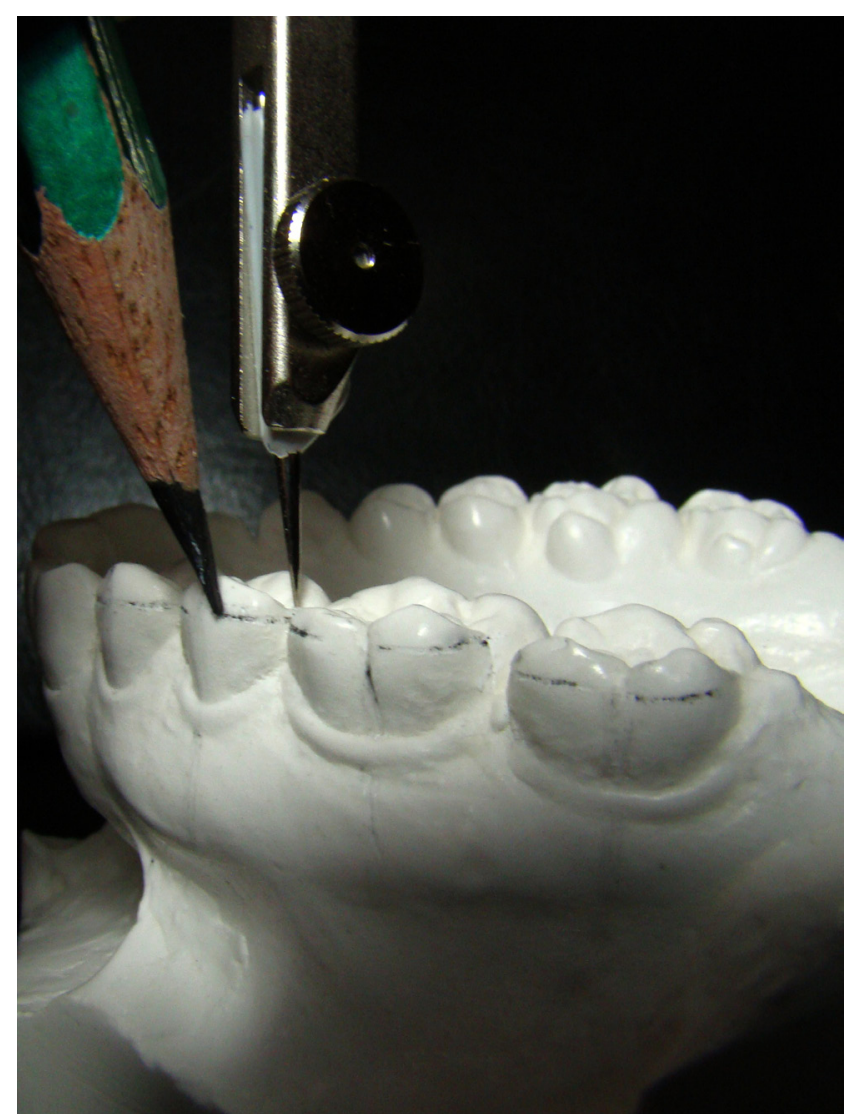

Figure 1. Mesial and distal points marked by using the marginal ridges as reference.

The occlusal third of the teeth was measured with a digital millimeter caliper Dentagauge $3^{\mathrm{TM}}$ (Erskine Dental, Macksville, New South Wales, Australia) following the convexity of the buccal surfaces (Figure 2). The distances were measured from the cusp tip to the line drawn on the marginal ridges of premolars, and on molars, from the tip of the mesiobuccal cusp to the reference line. The values obtained by 3 examiners were processed with Microsoft Excel 2010 software in order to determine the mean values. 


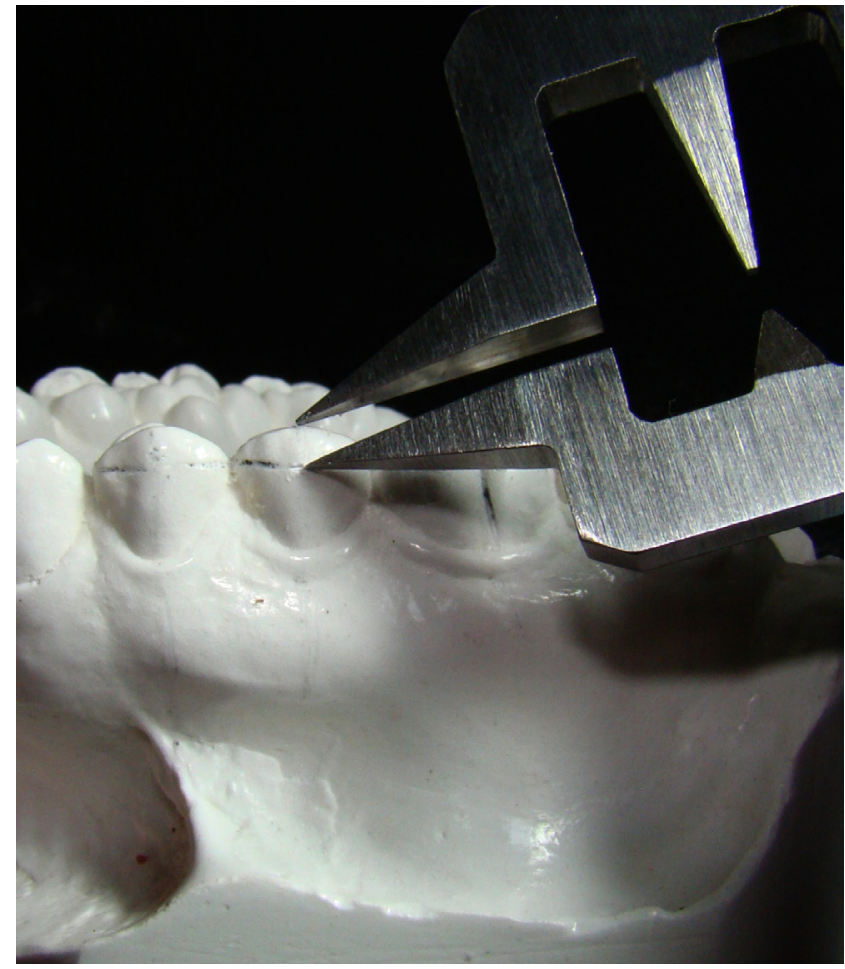

Figure 2. Occlusal third measurement with a digital millimeter caliper.

The means were then compared with the values of Alexander and Viazis' equations (Table 1). The mean size of the occlusal third of the second lower right premolar (tooth \#45) was used as a reference (x) for comparison with the values of the other teeth, given that these teeth had shorter crowns in the occlusogingival direction [13].

Alexander and Viazis predefined the use of the same placement value $(\mathrm{x})$ for all first and second premolars. Therefore, a comparison was made between the mean size of the occlusal third of tooth \#45 (value $\mathrm{x}$ ) with the mean size of the occlusal third of the first and second premolars of the sample.

As the equation $(\mathrm{x}-0.5 \mathrm{~mm})$ was recommended by the authors for the first molars, $0.5 \mathrm{~mm}$ was subtracted from the measured value ( $\mathrm{x}$ ) (tooth \#45). This referenced value was then compared to the occlusal third mean size of the first permanent molars of the sample.

For the second permanent molars the equation $(\mathrm{x}-1 \mathrm{~mm})$ was suggested, and therefore $1 \mathrm{~mm}$ was subtracted from the size of the occlusal third of tooth \#45. Subsequently, a comparison was made between this parameter and the mean occlusal third size of the second molars of the sample.

The lines traced on all models were erased and the process was repeated by 3 previously calibrated examiners, with similar instruction level in the pertinent area and the intraclass correlation coefficient (ICC) was used, with a significance level of $5 \%(\mathrm{p} \leq 0.05)$.

The results were subjected to the Kolmogorov-Smirnov normality test. Data Gaussian distribution test was performed as well as One-way ANOVA with 5\% alpha level significance.

\section{RESULTS}

The value (x) proposed by Alexander and Viazis, for positioning brackets on second premolars, disclosed no statistically significant difference with the values of the occlusal third of these sample teeth ( $p>0.05$ ) (Table 1).

Table 1. Vertical bracket placement patterns for posterior teeth.

\begin{tabular}{ccc}
\hline \multirow{2}{*}{ Teeth } & \multicolumn{2}{c}{ Vertical placement pattern } \\
\cline { 2 - 3 } & Alexander & Viazis \\
\hline $14,24,34$ and 44 & $x$ & $x$ \\
$15,25,35$ and 45 & $x$ & $x$ \\
$16,26,36$ and 46 & $x-0.5 \mathrm{~mm}$ & $x .0 .5 \mathrm{~mm}$ \\
17 and 27 & $x-1 \mathrm{~mm}$ & $x-1 \mathrm{~mm}$ \\
37 and 47 & non available & $x-1 \mathrm{~mm}$ \\
\hline
\end{tabular}

Analysis of variance (ANOVA) revealed significant differences $(p<0.001)$ between the value $(x)$ recommended by the authors for the bracket placement in the first premolars in relation to the actual dimension of the occlusal third of these sample teeth (Table 2).

The comparison between the adopted value $(\mathrm{x}-0.5) \mathrm{mm}$ for first permanent molars to the size of the occlusal third of the sample showed no significant differences $(\mathrm{p}=0.0531)$ (Table 2).

The size of the second permanent molars occlusal third in the sample disclosed significant differences in relation to the vertical positioning value of $(\mathrm{x}-1) \mathrm{mm}$ stated by those authors $(\mathrm{p}<0.001)$ (Table 2).

Table 2. Comparison between the placement patterns and the occlusal third of sample teeth.

\begin{tabular}{|c|c|}
\hline Tooth & $\begin{array}{c}\text { Mean } \pm \text { stardard-deviation } \\
(\mathrm{mm})\end{array}$ \\
\hline 15 & $2.227 \pm 0.321^{*}$ \\
\hline 25 & $2.200 \pm 0.331^{*}$ \\
\hline 35 & $2.337 \pm 0.310^{*}$ \\
\hline 45 (Value $x)$ & $2.293 \pm 0.290^{*}$ \\
\hline 14 & $2.696 \pm 0.437$ \\
\hline 24 & $2.634 \pm 0.380$ \\
\hline 34 & $2.645 \pm 0.320$ \\
\hline 44 & $2.630 \pm 0.357$ \\
\hline 45 (Value $x)$ & $2.293 \pm 0.290$ \\
\hline 16 & $1.876 \pm 0.290^{*}$ \\
\hline 26 & $1.870 \pm 0.255^{\star}$ \\
\hline 36 & $1.840 \pm 0.243^{\star}$ \\
\hline 46 & $1.845 \pm 0.248^{\star}$ \\
\hline $45-0.5 \mathrm{~mm}$ (Value $x-0.5 \mathrm{~mm})$ & $1.793 \pm 0.290^{*}$ \\
\hline 17 & $1.912 \pm 0.321$ \\
\hline 27 & $1.877 \pm 0.311$ \\
\hline 37 & $1.909 \pm 0.323$ \\
\hline 47 & $1.877 \pm 0.275$ \\
\hline $45-1 \mathrm{~mm}$ (Value $\mathrm{x}-1 \mathrm{~mm})$ & $1.293 \pm 0.290$ \\
\hline
\end{tabular}

$* p \geq 0.05$. 


\section{DISCUSSION}

Vertical positioning errors may be caused by limitations during bonding, as improper visualization of the teeth's long axis due to malocclusion of the patient $[5,16]$, optical distortion of the actual proximal dimensions of teeth, diminute brackets size and morphological teeth variability in different individuals [17-19]. These errors may cause several consequences such as tooth intrusion/ extrusion, uneven marginal ridges, changes in torque [17] and in the buccolingual position of the tooth [20], inadequate intercuspation and inability to attain mutually protected guidances [5], thereby increasing the risk of relapse [17].

The marginal ridges leveling of adjacent teeth constitutes one of the prerequisites of a successful orthodontic treatment as it helps to level the cementoenamel junction of these teeth, performing bone level planning and achieving ideal occlusal contacts with greater ease $[1,20]$.

Studies of vertical orthodontic accessories positioning are recurrent in the literature. Alexander and Viazis' methods, routinely employed by orthodontists aiming marginal ridges leveling, stated that the vertical brackets placement pattern should follow an equation starting from the position adopted on second premolars. The position of the lower second premolar bracket was assigned the value of $(\mathrm{x})$ as a reference, given that it is usually the smallest lower posterior tooth in the dental arch. The remaining teeth should follow an equation according to the size of their crowns, which would imply the increase or decrease of a few millimeters [12].

Angle [9] and Andrews [10] recommend that brackets should be placed at the center of the tooth labial surface. However, leveling hardly ever occurs when the placement method used is based only on teeth of normal size and with no wear [11]. Furthermore, other authors used the marginal ridges as reference for positioning orthodontic brackets $[11,14]$ but these techniques have not become as widespread as Alexander and Viazis' methods.

The comparison of second premolars pattern recommended by Alexander and Viazis with the occlusal third of these sample teeth found no significant statistical difference $(p>0.05)$. This study corroborated the use of the same value ( $\mathrm{x}$ ) for all second premolars, as they displayed similar dimensions (Table 2).

The aforementioned authors determined that the first premolars brackets should also be bonded using the same value used for the second premolars. However, this study found a significant difference $(\mathrm{p}<0.001)$; indicating that the first premolars have an occlusal third size with greater dimension in relation to second premolars (Table 2).

There was no statistically significant difference $(\mathrm{p}=0.0531)$ between the value $(\mathrm{x}-0.5 \mathrm{~mm})$ recommended by Alexander and Viazis for permanent first molars positioning and the values found in this study. This corroborated that the occlusal third of these teeth has a smaller size compared to the reference (second premolars) (Table 2).

Furthermore, the authors suggested that second permanent molar brackets should be placed at a position
$1 \mathrm{~mm}$ occlusally $(\mathrm{x}-1 \mathrm{~mm})$ compared to the value adopted for second premolars (x). This predetermined value did not coincide with the occlusal third size of the teeth in the sample $(\mathrm{p}<0.001)$, and therefore failed to induce marginal leveling (Table 2).

This value of $(x-1 \mathrm{~mm})$ is meant to be used to place the second molars in an infraocclusion position. Physiologically these teeth are proximally unleveled relative to the first permanent molars, enabling the distal cusp of the first molars to adjust and a normal occlusion to be established according to Andrew's keys $[12,13]$.

In this study the process of measuring the casts was performed by three different examiners with the purpose of determining the actual outcome, since an assessment made by a single examiner might reflect solely her own clinical skills $[15,17,18]$.

Previous study reported that all techniques that use predetermined bracket placement values - including Alexander and Viazis - have limitations and may fail to level the marginal ridges by the end of orthodontic treatment [17]. Given the anatomical variability between individuals and the fact that the placement techniques were based on mean values, an individualized treatment is required. Aiming the marginal leveling, one should employ only methods that use the marginal ridges instead of occlusal margins as a parameter for the bracket slots positioning.

Further studies should be conducted using a sample that takes into account the ethnic diversity of the population; in order to obtain a more individualized and accurate bracket placement pattern in relation to the ones that have been already created.

\section{CONCLUSIONS}

The present study confirmed that the values used to the placement of brackets on second premolars (x) and first permanent molars $(\mathrm{x}-0.5 \mathrm{~mm})$ proposed by Alexander and Viazis do promote the marginal ridges leveling. However, there is a need for individualization when positioning brackets on first premolars and second molars, since marginal leveling cannot be attained using the values proposed by Alexander and Viazis.

\section{REFERENCES}

1. Casko JS, Vaden JL, Kokich VG, Damone J, James RD, Cangialosi TJ, Riolo ML, Owens SE, Bills ED. Objective grading system for dental casts and panoramic radiographs. Am J Orthod Dentofacial Orthop 1998; 114:589-99.

2. Suarez C, Vilar T. The effect of constant height bracket placement on marginal ridge levelling using digitized models. Eur J Orthod 2010;32: 100-5

3. Creekmore TD, Kunik RL. Straight wire: the next generation. Am J Orthod Dentofacial Orthop 1993;104:8-20

4. Mezomo M, de Lima EMS, de Menezes LM, Weissheimer A. Indirect bonding with thermal glue and brackets with positioning jigs. Progress in Orthodontics 2011; 12:180-5.

5. Balut N, Klapper L, Sandrik J, Bowman D. Variations in bracket placement in the preajusted orthodontic appliance. Am J Orthod Dentofacial Orthop 1992;102:62-67.

6. McLaughlin RP, Bennet JC. Finishing and detailing with a preadjusted appliance system. J Clin Orthod 1991;25:251-64. 
7. Carlson SK., Earl J. Bracket positioning and resets: five steps to align crowns and roots consistently. Am J Orthod Dentofacial Orthop 2001:119:76-80.

8. Nichols DA, Gardner G, Carballeyra AD. Reproducibility of bracke positioning in the indirect bonding technique. Am J Orthod Dentofacial Orthop 2013;144:770-6.

9. Angle EH. The latest and best in orthodontic mechanism. Dent Cosmos Andrews LF. The straight-wire appliance explained and compared. J Clin Orthod 1976;10:174-95.

10. Kalange JT. Ideal appliance placement with APC brackets and indirect bonding. J Clin Orthod 1999;33:516-26.

11. Alexander RG. The vari-simplex discipline. Part 1: concept and appliance design. J Clin Orthod 1983;17:380-92.

12. Viazis AD. Bioefficient therapy. J Clin Orthod 1995;29:555-68.

13. Ricketts RM. Bioprogressive therapy as an answer to orthodontic needs. Part I. Am J Orthod Dentofacial Orthop 1976;70:241-68.

14. Joiner M. In-house precision bracket placement with the indirect bonding technique. Am J Orthod Dentofacial Orthop 2010;137:850-4

15. Philips WH. Bonding - Part I. J Clin Orthod 1980;14: 391-411.
16. Germane N, Bentley Jr BE, Isaacson RJ. Three biologic variables modifying faciolingual tooth angulation by straighht-wire appliances. Am J Orthod Dentofacial Orthop 1989:96:312-9.

17. Koo BC, Chun-His C, Vanarsdall RL. Comparison of the accuracy of bracket placement between direct and indirect bonding techniques. Am J Orthod Dentofacial Orthop 1999;116:346-51.

18. Sondhi A. The implications of bracket selection and bracket placement on finishing details. Semin Orthod 2003;9: 155-64.

19. McLaughlin RP, Bennett JC. Bracket placement with the preadjusted appliance. J Clin Orthod 1995;29:302-11.

20. Armstrong D, Shen G, Petocz P, Ali Darendelier M. A comparison of accuracy in bracket positioning between two techniques - localizing the centre of the clinical crown and measuring the distance from the incisal edge. Eur J Orthod 2007;29:430-6. 